\title{
Review: A Companion to Shakespeare
}

\section{Journal Article}

Author(s):

Vickers, Brian

Publication date:

2001

Permanent link:

https://doi.org/10.3929/ethz-b-000423112

Rights / license:

In Copyright - Non-Commercial Use Permitted

Originally published in:

The review of English studies 52(208), https://doi.org/10.1093/res/52.208.566 
that the shift of control to the dramatic companies proposed by Hunter is not compatible with the degree of authorial autonomy posited by Bevington. A lack of communication/consistency is also evident in the overall organization of the work. Bevington's edition of Midas departs from both the practice of previous volumes, and Hunter's relatively economical approach in the present edition, by the introduction of a number of 'Longer Notes', reminiscent of Harold Jenkins's edition of Hamlet (1982). The decision to adopt this practice at this stage in the series is surprising in that Midas is a far less complex work than either Sappho and Phao or Endymion, while the decision to devote a longer note to the technical terms of Midas but not to those of Galatea (which are arguably more abstruse) again suggests the incoherence of the editorial endeavour.

A number of recent editors have attempted to revise the titles by which certain Renaissance plays have come to be known. The present volume contributes to this development by its preference for Galatea over Gallathea, the title assigned to the play by successive generations of editors. The change is justified on the grounds that it is not only etymologically more correct but conforms to the custom of modernizing the names in this series' (p. 28). Leaving aside the question of whether the modern editor is justified in emending nomenclature on the grounds of etymological 'correctness', the change points to a further inconsistency in editorial practice. Though Lyly's second play appears in this series under the title of Sappho and Phao, no explanation is offered for the departure from the Sapho and Phao of earlier editions. Presuming the change to have been made on the basis of the criteria formulated in the present volume, the reader is left to speculate why 'Sapho' had been emended and 'Phao' retained. In the case of the shift from Gallathea to Galatea, it seems likely that any minor scholarly advantages achieved by the change will be outweighed by bibliographical confusion in an age of search engines and computer-generated lists.

The middle years of the twentieth century saw a new dawn in Lylian studies that promised to undo the neglect of over three centuries. The subsequent critical revolution contributed to the movement to reposition the Lylian corpus within English literary studies, though the want of modern editions has inevitably stunted that process. Galatea, the more major of the two plays in the present volume, has lain at the heart of that critical endeavour, and many of the issues Hunter raises and finds difficult of resolution have been recently addressed. This edition can only serve, by its very prominence, to check this advance. Both Lyly and Lylian scholars deserved better.

LEAH SCRAGG University of Manchester

David scott kastan (ed.). A Companion to Shakespeare. Pp. xii+524. Oxford: Blackwell, 1999. f75.

The 'Companion to Shakespeare Studies' is by now a well-established genre. Cambridge University Press brought out the first one in 1934, edited by Harley Granville-Barker and G. B. Harrison, which consisted of sixteen essays (408 pages), including one by T. S. Eliot. That volume, reprinted ten times, was replaced in 1971 by A Nem Companion to Shakespeare Studies, edited by Kenneth Muir and S. Schoenbaum, consisting of eighteen essays (298 pages). Only fifteen years later Cambridge brought out a new version, now named The Cambridge Companion to Shakespeare Studies, edited by Stanley Wells, consisting of seventeen essays (329 pages). Cambridge's virtual monopoly on this genre was shattered in 1985 when Scribner's published the huge three-volume study, William Shakespeare: His World, his 
Work, his Influence, edited by John F. Andrews, and containing sixty essays (954 pages, double-column). David Scott Kastan now challenges comparison with his predecessors in a volume containing twenty-eight essays (524 pages).

Readers of such collections may hope to find that each essay has been written by someone knowledgeable in that field; that the authors will give a clear exposition of their topic, outline points under dispute, and perhaps make an original contribution; and that both contributors and editors will provide accurate and helpful suggestions for further reading. Professor Kastan's volume meets some of these expectations, but disappoints others.

The book's orientation is, vaguely, 'new historicist'. In his introduction David Scott Kastan describes the collection's goal as being 'to see Shakespeare's art' in the context of the 'imaginative, material, and institutional' conditions 'that enabled and, in some cases, inhibited' it, and to investigate the 'networks of dependency' and 'specific institutional contexts of his playmaking', since 'all intellectual and artistic activity is dependent in . . . imaginative and material ways; it is necessarily social' (pp. 4-5). Rather more space has been given to the material and institutional contexts than to Shakespeare's artistry. No less than six essays are devoted to the socio-politicalreligious background, with some overlapping: an essay on 'Shakespeare and Political Thought' is followed by another on 'Political Culture'. Under 'Playing' we find an essay on 'Licensing and Censorship'; under 'Printing' there is one on 'Liberty, Licence, and Authority: Press Censorship and Shakespeare', an unnecessary duplication. The volume's planning is deficient in other respects. There is no treatment of the intellectual world in which Shakespeare lived, although concepts of the psyche, the human body, and the nature of man and the cosmos were at least as important as its surviving material traces to a playwright whose 'engagement with his own world', according to Kastan, 'is the most vital record we have of that world's struggle for meaning and value' (p. 4). Although paying lip-service to Shakespeare's artistry, there is no study of how he shaped his source material into coherent plays, often with multilevelled plots, and no discussion of Renaissance literary theory. There are no essays on music, the visual arts, emblem books, or the masque.

As for the quality of the volume, Professor Kastan drops editorial modesty and adopts a blurb-writer's hype to assure us that the essays he has collected 'represent the best of modern scholarship. Individually, each stands as a definitive account of its subject; collectively, they form a detailed and arresting mosaic of Shakespeare's artistic environment' (p. 5). These are high but empty claims, since none of these essays can be called 'definitive'. David Bevington's opening account of 'Shakespeare the Man' recycles the usual clichés about his life, such as describing the 'swipe' administered by Jonson, 'chiding [Shakespeare] for having had only "small Latin and less Greek", (pp. 10-11). But Jonson writes 'And though thou hadst small Latin', where 'hadst' is a subjunctive, and the sentence means 'Even if you had had little scholarship' - which was not the case-'I would not seek to honour you by comparing you with Aeschylus \& co., but would call them back to witness your excellence', a rare tribute (see B. Vickers (ed.), English Renaissance Literary Criticism (1999), 539). Bevington repeats the bad old tradition by which Greene's description of Shakespeare as an 'upstart crow . . . beautified with our feathers' is seen as an accusation of plagiarism, rather than a university graduate's attack on the common players. He also repeats the error by which Chettle's apology to one of the writers slandered by Greene, affirming personal knowledge of his 'uprightness of dealing . . . and his facetious grace in writing', is said to refer to Shakespeare, whereas Peele was meant (see Lucas Erne, 'Biography and Mythography: Reading Chettle's Alleged Apology to Shakespeare', English Studies, 79 
(1988), 430-40). When Bevington interprets the plays, the clichés of American feminist and psychoanalytical criticism take over. The plays of the $1590 \mathrm{~s}$, with their admired but feared father-figures, 'seem strikingly relevant to the life cycle of the author himself' (p. 17); Lady Macbeth is 'a notable example of . . . "the suffocating mother" in Shakespeare's later plays' (pp. 17-18); Shakespeare's 'portrait of marriage in Othello' is 'an unparalleled nightmare of sexual jealousy'-a typical feminist reading, not mentioning Iago — which reveals the dramatist's 'own intense feelings about jealousy' (p. 18); Antony and Cleopatra is a 'portrayal of what we today would call midlife crisis', a 'predictable and unavoidable' stage in male development in which 'a man finds himself overwhelmed by fears of aging, loss of sexual potency', and so forth (p. 18); however, Antony is superior to 'the self-denying and anal Octavius Caesar' (p. 19). These stale and reductive readings hardly fulfil the editor's goal of allowing Shakespeare's 'own voice . . . to be heard' (p. 3).

Anyone expecting each essay to provide 'a definitive account of its subject' will be rudely surprised by Peter G. Platt's account of 'Shakespeare and Rhetorical Culture' (pp. 277-96). This begins, oddly enough, with Plato's notoriously biased attack on rhetoric, and within two pages has concluded that 'the rhetorical view of the world' is 'fictitious, constructed, and potentially false'. To justify this jaundiced dismissal Platt makes Claudius an exemplary figure, a character who 'links his own general duplicity to the deception of rhetoric' by comparing 'the harlot's cheek' to his 'most painted word' (p. 279). But both Plato and Claudius represent extreme positions, quite unrepresentative of rhetoric's serious involvement with democratic debate, liberty, and with cultivating the individual's abilities in self-expression The negative image persists when Platt tries to link rhetoric with 'Renaissance self-fashioning', emphasizing the 'amoral' element, and ending with Richard Crookback's boast that he can 'play the orator as well as Nestor' and 'change sides with Proteus for advantages'. The culmination of Platt's negative presentation of rhetoric is a reading of Bassanio's speech before the three caskets, in which his attack on false appearances-'the world is still deceiv'd with ornament'-includes the use of wigs (Merchant of Venice, III. ii. $73 \mathrm{ff}$.). Although Bassanio obviously uses 'ornament' to mean any cosmetic or false appearance, Platt insists on taking it as an attack on rhetorical ornament, proudly identifying it as 'a highly ornamented speech against ornament' (p. 293). Not only confusing two different meanings, Platt is unaware that the term ornatus in classical rhetoric actually carried the connotations of 'tools' or 'gear', those rhetorical devices which permitted effective persuasion. Far from being 'definitive', this essay offers a muddled and perverse account of its subject, and fails to offer readers any helpful entry point. Since Shakespeare used rhetorical figures more frequently than any other dramatist, about one every two lines in most of his plays, not to offer any discussion of this crucial expressive resource is a gross oversight, and it is equally disturbing that Platt should fail to mention the two indispensable modern works, T. W. Baldwin, Shakspere's Small Latine and Less Greeke (1944), and Sister Miriam Joseph, Shakespeare's Use of the Arts of Language (1947). This is not so much new historicism as new ignorance.

This essay suffers from too little, others from too much knowledge. Peter Lake, discussing 'Religious Identities in Shakespeare's England' (pp. 57-84), contributes by far the longest and most complex essay. Any reader who thought that Tudor England had only two religions, Protestant and Catholic, will be astonished by the proliferation of other religious groups documented here: Puritan ('first developed as a term of abuse by Catholic writers in the late 1560s': p. 62), Papist, Church Papist (a deeply ambivalent term, it transpires), 'hot Protestant', Familist (the Family of Love, 
whose surprising dissemination and acceptance has been recently established), Conformitan, and others. Professor Lake scrupulously distinguishes what anthropologists call 'actors' categories', the terms used by sixteenth-century authors to define themselves and indict others, from the even more bewildering and unstable terminology used by modern historians of various, often competing, schools: as he puts it, 'all [issues] turn on the definition and application of terms' (p. 58). Lake has an attractively trenchant manner dealing with revisionist historians, who 'turn received opinion almost symmetrically on its head' (p. 59), and have 'replicated almost perfectly the core assumptions and terms of reference of the jeremiads and complaint literature produced by perfect Protestant or Puritan commentators of the day', expanding 'the term "Catholic" to its maximum, paranoid' extent (p. 72). This high-powered study of 'the complexities of category formation' (p. 71) may be the book's outstanding contribution, but it will prove dauntingly difficult for all but the best-informed readers.

Fortunately, other contributors offer less difficult entries to their material. Susan Dwyer Amussen's description of 'The Family and the Household' (pp. 85-99), well illustrated from contemporary sources, is almost too simple. Her account of marriage promises de praesenti and de futuro recognizes none of the complexities which commentators on Measure for Measure have discovered. Ian W. Archer gives a lively account of 'Shakespeare's London' (pp. 43-56), dealing with population growth, social status (women 'enjoyed more independence in the capital because of the nature of their work'), and processes of inclusion and exclusion. Robert S. Miola contributes a learned but lucid account of 'Reading the Classics' (pp. 172-86), Scott McMillin a sensible if brief survey of 'Professional Playwrighting' (pp. 225-38), and Jonathan Hope a helpful study of 'Shakespeare's "Native English"' (pp. 239-55), equally at home in Tudor sources and modern linguistics (although it seems a misplaced authenticity to preserve the long f). Other helpful essays include William Ingram on 'The Economics of Playing' (pp. 314-27), S. P. Cerasano on 'The Chamberlain's-King's Men' (pp. 32845), and Andrew Gurr on 'Shakespeare's Playhouses' (pp. 362-76), including welcome ground-plans of the 1989 excavations of the Rose Theatre, and of the new Globe in Southwark.

Editorial supervision throughout the volume is patchy. Although most contributors add footnotes and a bibliography, David Daniell's engaging history of 'Reading the Bible' (pp. 158-71) has neither. William B. Long, describing English manuscript playbooks (pp. 414-33), apparently convinced that all previous scholarship is faulty, only includes references to his own work. Some contributors reveal unawareness of recent research. Miola continues to ascribe the 1592 translation of the pseudoPlatonic Axiochus to Spenser, when its real author was probably Anthony Munday (see The Spenser Encyclopedia (1990), s.v.). Both Rosalyn Knutson (p. 347) and Andrew Gurr (p. 365) think that the abbreviation 'ne' in Henslowe's Diary describes a new production, whereas it refers to one mounted at the Newington Butts theatre, as Winifred Frazer has shown ('Henslowe's "Ne"', Notes and Queries, 236 (1991), $34-5)$.

Proof-reading is equally unsatisfactory. Amussen's quotation of Sir John Oglander's moving tribute to the life-long help he had received from his 'most careful, thriving wife', who took personal responsibility for all household tasks and 'would wet her shoe to see it all herself acted', is ruined by the misprint 'show' (p. 87). Names are garbled: Chernaik appears as Cherniak (p. x), Robert Parsons as parsons (p. 64), Spenser as Spencer (p. 133), and the editor is placed at the University of Columbia (back flap), instead of Columbia University, NY. We have 'teachers' (p. xi) for 'teaches', 'principle' (p. 122) for 'principal', a 'dear introduction' (p. 255) for 'clear', 'who' (p. 375) for 
'whom', and patrons who are 'disinterested' (p. 328). Obvious typos include Latin Fiede (p. 471), and French lattre (p. 105), emphemeral (p. 52), Protestantanism (p. 68).

Scholars will certainly want to check out contributions in their fields, but the general reader, especially the beginning student, would be well advised to use the Cambridge Companion, the Scribner William Shakespeare (about to appear in an abridged version), or Russ McDonald (ed.), The Bedford Companion to Shakespeare: An Introduction with Documents (1996).

The publishers have evidently invested a lot of money in this book: it is a pity that their trust has not been better rewarded.

BRIAN VICKERS Centre for Renaissance Studies, ETH Zürich

PETER HOLland (ed.). Shakespeare and Narrative: Shakespeare Survey 53.

Pp. $x+358$. Cambridge: Cambridge University Press, 2000. £50.

The first issue of the journal Shakespeare Survey was published in 1948, and carried a statement of purpose from its editor, Allardyce Nicoll: 'Shakespeare Survey, sponsored by a university [the University of Birmingham], a theatre [the Shakespeare Memorial Theatre] and a library rich in documents relating to Elizabethan times [the Shakespeare Birthplace Trust], aims at appealing to the scholar, the theatre-worker and the archivist, while at the same time presenting material likely to be of value to a wider public generally interested in Shakespeare.' None of the fifty-two volumes since this first one has contained any further editorial detail about its specific mission; none, perhaps, has needed to. Shakespeare Survey has, in almost entirely positive ways, remained remarkably unchanged since its inception: an annual hardback volume with an overall theme to which the majority of essays address themselves; a survey of theatre performances and detailed review of major, particularly RSC, productions; and a selective account of publications under three headings, 'Critical Studies', 'Shakespeare's Life, Times and Stage', and 'Editions and Textual Studies'. Three editors have held the reins during the journal's first fifty years, and Peter Holland now takes over as its fourth. As befits the best traditions of Shakespeare Survey, no immediate changes from previous policy are evident in this first volume under his editorship, although it is now possible for contributors to send submissions by e-mail attachment.

The format and contributions to volume 53, Shakespeare and Narrative, amply demonstrate why Shakespeare Survey has retained its central position in Shakespeare scholarship. The pedigree of the contributors is beyond reproof, including A. D. Nuttall on A Midsummer Night's Dream, E. A. J. Honigmann on King Fohn, and Jill L. Levenson on Romeo and fuliet. There is a lively range of contributions, from Michael D. Bristol's careful negotiation of the kinds of inferences and intuitions brought to Shakespeare in 'vernacular criticism', to Rex Gibson's unpatronizing account of teaching Shakespeare in schools so as to give 'legitimacy to students' own transformations, abridgements and inventions' (p. 163). Julia Griffin's sensitive analysis of fin-de-siecle refigurings of the epicene relationship between Prospero and Ariel is a welcome addition to the study of Shakespearian afterlives; Phyllis McBride's study of the nineteenth-century American Miranda is its critical counterpart. Long before Shakespeare in performance became an active area of scholarly research, Shakespeare Survey pioneered serious and informed criticism of theatre productions, and this is represented here by Robert Smallwood's detailed account of professional productions during 1999, and by Edward L. Rocklin's suggestive essay on the endings 